\title{
No agreement yet over minimising bureaucratic barriers to exchange
}

INTERNATIONAL scientific exchange must not merely take place; it must be seen publicly to take place. That is how one delegate to the Hamburg Scientific Forum has explained its purpose. The Forum has brought together leading scientists from Europe and North America for two weeks in the service of what has been referred to as the CSCE process, i.e. the implementation of the Helsinki Accords on peace and security in Europe.

The Soviet invasion of Afghanistan and the internal exiling of Academician Andrei Sakharov to Gor'kii mean that the forum is convening among what Dr Armand Boever of Luxembourg calls the "menacing strom cloud of the last few weeks". Inevitably the opening statements by the participating countries delivered last week, put considerable emphasis on the concepts of academic freedom and the responsibility of scientists towards society.

Strong statements on the human rights issue, sometimes citing the Soviet Union by name, sometimes, as did Dr Andre Lwoff (France), referring to breaches of the Helsinki accords in "a certain country", drew an emphatic refutal from the leader of the Soviet delegation, Dr Nikolai Blokhin. "The basic objection is that we observe our laws", he protested, speaking under the right to reply. "There have been no violations of Soviet law in the Sakharov affair. And Gor'kii is not exile. I myself was born there."

This undertone of confrontation which ran through the entire two and a half days of opening statements, focused attention on the fact that the forum was not, properly speaking, a scientific meeting. When, finally, the preliminary statements were over, and the meeting divided up into working groups on pre-selected topics (alternative energy sources, food production, cardiovascular, tumour and virus diseases, human environment and urban development), the scientists in the various delegations, irrespective of their countries' political system, seemed only too anxious to come to grips with the basic problem of promoting international scientific exchanges.

The majority of western delegates felt that if the forum were to make any real contribution to international exchange as opposed to simply demonstrating scientific cooperation in the service of detente - it could best do so by endeavouring to eliminate or at least minimise the bureaucratic barriers to such exchange.

Since almost all the 35 delegations contained a sprinkling of bureaucrats, who sat in on the various working groups, the forum seemed an ideal opportunity for the scientists to make known their grievances against official frustration and obfuscation. This, however, various Soviet delegates were unwilling to allow. Repeated attempts to raise, in the closed working sessions, questions of visas, the cancellation of visits at the last moment for no clear reason, the substitution at conferences of some scientific nonentity for the speaker originally invited, and all the other difficulties and disappointments familiar to the would-be hosts of Soviet scientists, were quashed by the various Soviet representatives. "We are not here to discuss such matters" was their attitude in which case, one might well ask with $\mathrm{Dr}$ Th. P. Tassios (Greece) what unique purpose the forum could serve.

Dr Tassios suggested that a permanent steering committee should be established to "define and shape" scientific "goals" and to deal with the whole problem of the ethics of science. To judge from the opening statements and the general tone of the Forum so far, this is a minority view. Most delegates, at least from outside the socialist bloc, seem to agree with Lord Todd (UK) that whatever the forms of future cooperation to be agreed by the Forum, more organisations to take scientists away from the bench and into the conference jetset are not needed.

Vera Rich

United Kingdom

\section{Split over admissible evidence at test drilling inquiry}

THE UK's first public inquiry into test drilling for the possible disposal of high level radioactive waste got off to a stormy start in Ayr, Scotland last week, with claims that the government was trying to cover up the real issues by restricting the type of evidence. The Scottish office has ruled that it will accept testimony only on the limited question of test site drilling. Community groups, fearing that limited approval for site drilling will create a precedent that will prejudice further hearings, have argued that evidence on the question of the suitability of the area for waste disposal itself ought to be admitted.

The inquiry had been set up to consider a planning application lodged by the United Kingdom Atomic Energy Authority two years ago to test drill an area of hard granite above Loch Doon in the Galloway Hills possible sites in the UK for Britain's first underground radioactive waste repository. Soon after the planning application was lodged the local authority, Kyle and Carrick District Council, turned it down. The inquiry that opened in Ayr last week is the result of the UKAEA appealing against that decision.

The first witness, Scottish Under
Secretary William Scott, stressed that the government had not yet decided on the best way of disposing of nuclear waste. Research was also planned on waste disposal on and under the sea bed, he said. Under cross examination Scott admitted that he could give no firm undertaking that all the other 15 shortlisted sites would be fully investigated at a cost of $£ 1$ million each.

Byron Lintern, a senior scientific officer from the Institute of Geological Sciences, and a witness for the UKAEA, explained that the proposed test drilling would involve sinking approximately 40 boreholes over a wide area at varying depths down to a maximum of $500 \mathrm{~m}$. Two $15 \mathrm{~m}$ rigs would be needed and a staff of about 15. Drilling would be phased over a two or three year period to avoid disturbing local birds during their breeding cycle. The cost of test drilling had risen from $£ 150,000$ in 1978 to $£ 450,000$ in 1980 , he said.

Dr Lewis Roberts for the UKAEA told the inquiry that the UK currently had about $1,000 \mathrm{~m}^{3}$ of high level waste stored in steel tanks at Windscale. It was proposed to glassify the waste, encase it in noncorrosive metal and then find the most suitable place to store it. A safe home had to be provided for around 500 years, by which time gamma radiation would have decayed to acceptable levels. Roberts rejected Kyle and Carrick's suggestion that the drilling work was "premature."

ONE of the main objectors at the formal inquiry, the Scottish Conservation Society, organised its own parallel hearing - the People's Planning Inquiry Commission to discuss nuclear waste dumping, safety and alternative methods of disposal, topics forbidden at the main inquiry. $99 \%$ of those attending the 'People's Inquiry' were opposed to the drilling proposals.

The UKAEA declined an invitation to attend, but paid the expenses of Professor John Fremlin, a radiation biologist, who told the meeting that there was little likelihood of the proposed dump causing serious contamination. It would take 100,000 years for the waste to find its way to the surface, he said, and in the worst possible situation would only then result in one death per decade.

Ted Stevens

Ted Stevens is a freelance journalist specialising in planning 